\title{
AOR
}

Selected Papers of \#AoIR2019:

The $20^{\text {th }}$ Annual Conference of the Association of Internet Researchers

Brisbane, Australia / 2-5 October 2019

\section{SPOTIFY AND NETFLIX AS INNOVATIONS: STREAMING MEDIA HISTORY IN THE LIGHT OF INNOVATION THEORY}

Anders Fagerjord

Department of Linguistic, Literary and Aesthetic Studies, University of Bergen

\section{Introduction}

Streaming services such as Spotify and Netflix have taken over large portions of the market for music and audio-visual entertainment worldwide, and in April 2018, music streaming had surpassed physical sales in revenue worldwide (Ball \& Auchard, 2018), challenging and possibly destroying established industries. The events that led to this innovation has not yet been charted, however. Most writers who have studied streaming services have included some parts of their history, but the different industries have not yet been compared.

This paper is a study of the history of streaming media services under the lens of innovation theory. Innovation theory is a broad area, covering studies of individuals, organisations, and networks, often from systems or economic perspectives, including studies of history, strategy, and policy studies (Fagerberg, 2006). Central authors include Schumpeter and his use of Marx's concept "creative destruction" (Schumpeter, 2010), von Hippel, who wrote about "user innovation" (von Hippel, 1988), and Christensen (1997) with his very influential concept of "disruption".

\section{Method}

In this ongoing study, we collect and systematize the findings of earlier histories of streaming technology under the lens of systems-oriented innovation theory (Edquist, 2006). To date, we have consulted about 50 papers, chapters and book-length studies. These are contextualised with other histories of computer development (e.g., Friedman, 2017).

\section{Results}

Suggested Citation (APA): Fagerjord, Anders. (2019, October 2-5). Spotify and Netflix as Innovations: Streaming Media History in light of Innovation Theory. Paper presented at AoIR 2019: The $20^{\text {th }}$ Annual Conference of the Association of Internet Researchers. Brisbane, Australia: AoIR. Retrieved from http://spir.aoir.org. 
Streaming services are similar to most innovations in that "what we think of as a single innovation is often the result of a lengthy process involving many interrelated innovations" (Fagerberg, 2006). In the current literature, we see described many different stories of parts of what is now known as streaming. One storyline is the idea itself: Music and video on demand is a very old idea, imagined since the invention of the telephone (Fagerjord et.al., 2010; Williams, 1975) Another history is the many different technologies have been used in attempts to realise this idea. Compression technology is one important factor, and major milestones were the inventions of MP3 (1991-93) and AAC (1997) encoding of music files, and H.263 and H.264 for video (1996 and 2003). These file formats were popularised in part by companies such as Apple and Adobe, and made use of by companies such as Napster, Apple, YouTube, and Pirate Bay.

A history of streaming technology must also include infrastructure such as broadband cable networks and mobile networks for telephony and data traffic, important devices such as Apple's iPhone that launched the smartphone revolution (Snickars, 2012), but also the enormous increase in computer power, exploded by the use of networked server clusters running Hadoop and similar software (Friedman, 2017).

For music, the history is focussed on the "pirate wars" between music sharing systems and record companies, often described as reconciled by iTunes music, Spotify, and others (Spilker, 2017).

Histories of Netflix tend to focus on its algorithmic recommendation engine (Arnold, 2016; Madrigal, 1 January 2014; Smith-Rowsey, 2016; Finn, 2017) and changes in consumer behaviour, although binge-watching was described already in the age of VHS video, (Jenner, 2016). Interestingly, YouTube tends to be described as its own genealogy (Burgess \& Green, 2009; Prelinger, 2009; Snickars \& Vonderau, 2009; Levy, 2011) although a few have connected it to the general television industry (Evens \& Donders, 2018; van Dijck, 2013; Lotz, 2017).

\section{Discussion}

Streaming media is not one innovation, but a collection of many. Although it certainly is a technology shift, the most important event is probably that of aligning rights management. Music, television, and film has been, and continue to be quite different industries with different organisation, business models, distribution, and rights management. These differences can be seen in the different kinds of offering in different services: Music services have comprehensive, and quite similar catalogues, while television and film sites compete with unique material. Although innovation theory is a vast field, outsiders to its literature tend to focus on "disruption". It is interesting to note that streaming services hardly can be considered disruptions by Christensen's original definition of small firms catering to small niche markets with initially inferior technology.

Streaming services are also a telling example of the role of technology in media change: Technology alone cannot explain the differences we see between the music and television streaming services, as they are historically rooted in different organisations, business models, regulatory policies and use, including pirate practices. 


\section{References}

Arnold, S. (2016). Netflix and the myth of choice/participation/autonomy. In K. McDonald \& D. Smith-Rowsey (Eds.), The Netflix effect: Technology and entertainment in the 21st century (pp. 49-62). New York: Bloomsbury.

Ball, T., \& Auchard, E. (2018, c). Music streaming overtakes physical sales for the first time -industry body. Reuters.com. Retrieved from https://www.reuters.com/article/music-sales/music-streaming-overtakes-physicalsales-for-the-first-time-industry-body-idUSL8N1S143H

Burgess, J., \& Green, J. (2009). YouTube: Online video and participatory culture. Cambridge: Polity.

Christensen, C. (1997). The innovator's dilemma: When New Technologies Cause Great Firms to Fail. Cambridge, Massachusetts: Harvard Business Review Press.

Edquist, C. (2006). Systems of Innovation: Perspectives and Challenges. In J. Fagerberg \& D. C. Mowery (Eds.), The Oxford handbook of innovation. New York: Oxford University Press. doi:10.1093/oxfordhb/9780199286805.003.0001

Evens, T., \& Donders, K. (2018). Platform power and policy in transforming television markets. Cham: Palgrave Macmillan.

Fagerberg, J. (2006). Innovation: A Guide to the Literature. In J. Fagerberg \& D. C. Mowery (Eds.), The Oxford handbook of innovation. New York: Oxford University Press. doi:10.1093/oxfordhb/9780199286805.003.0001

Fagerjord, A., Maas $\varnothing$, A., Storsul, T., \& Syvertsen, T. (2010). High risk, strong belief: Images of the future in the media industry. Nordicom Review, 31, 3-16. Retrieved from http://www.nordicom.gu.se/common/publ_pdf/325_fagerjord\%20et\%20al.pdf

Finn, E. (2017). What algorithms want: Imagination in the age of computing (Kindle ed.). Cambridge, Massachusettes: MIT Press.

Friedman, T. L. (2017). Thank you for bering late: An optimist's guide to thriving in the age of accelerations. London: Penguin.

Jenner, M. (2016). Is this TVIV? On Netflix, TVIII and binge-watching. New Media \& Society, 18(2), 257-273. doi:10.1177/1461444814541523

Levy, S. (2011). In the plex: How Google thinks, works, and shapes our lives (Kindle ed.). New York: Simon \& Schuster.

Lotz, A. (2017). Portals: A treatise on Internet-distributed television. Ann Arbor, MI: Michigan Publishing. doi:http://dx.doi.org/10.3998/mpub.9699689

Madrigal, A. C. (2014). How Netflix reverse engineered Hollywood. The Atlantic.

Prelinger, R. (2009). The appearance of archives. In P. Snickars \& P. Vonderau (Eds.), The YouTube reader (pp. 268-274). Stockholm: Mediehistoriskt arkiv.

Schumpeter, J. A. (2010). Capitalism, socialism and democracy. Routledge: London.

Smith-Rowsey, D. (2016). Imaginative indices and deceptive domains: How Netflix's categories and genres redefine the long tail. In K. McDonald \& D. Smith-Rowsey (Eds.), The Netflix effect: Technology and entertainment in the 21st century (pp. 63-79). New York: Bloomsbury. 
Snickars, P. (2012). A walled garden turned into a rainforest. In P. Snickars \& P. Vonderau (Eds.), Moving Data: The iPhone and the Future of Media. New York: Columbia University Press.

Snickars, P., \& Vonderau, P. (2009). Introduction. In P. Snickars \& P. Vonderau (Eds.), The YouTube reader. Stockholm: Mediehistoriskt arkiv.

Spilker, H. (2017). Digital music distribution: The sociology of online music streams. London: Routledge.

van Dijck, J. (2013). The Culture of Connectivity: A critical history of social media (Kindle ed.). Oxford: Oxford University Press.

von Hippel, E. (1988). Sources of Innovation. New York: Oxford University Press. Retrieved from https://ssrn.com/abstract=2877276

Williams, R. (1975). Television: Technology and Cultural Form. New York: Schocken. 